\title{
The Korean War and US-Indonesia Relations, 1950-1954
}

\author{
Richard Mason \\ Institute of Malaysian and International Studies (IKMAS) \\ Universiti Kebangsaan Malaysia \\ mason5565@yahoo.com
}

DOI: https://doi.org/10.32890/jis2015.11.4

\begin{abstract}
The Korean War, which broke out very closely upon the heels of the Communist victory in China, immediately assumed global implications beyond the boundaries of the Korean Peninsula. Essentially a Korean civil war, it immediately became a major 'hot war' in the Cold War in Asia. This paper discusses the relations between the United States and Indonesia in the aftermath of the North Korean attack on South Korea, covering the period from the outbreak of the war in 1950 through to the end of the war in 1954. The paper explores the various ways in which the United States attempted to co-opt and coerce Indonesia into the Western camp in the Cold War, and Indonesia's responses thereto. The central theme of the paper is the interplay between the United States' policy of containment and the Indonesian policy of non-alignment in the Cold War. An examination of the United States' policy toward Indonesia, a non-communist but non-aligned nation, vis-à-vis the Korean War, would serve to illustrate the dynamics and nature of the Cold War in Southeast Asia.
\end{abstract}

Keywords: The Korean War, Cold War, United States, Indonesia, containment, non-alignment.

\section{Introduction}

The 'Korean War' broke out in June 1950 and lasted until 1954. Following very closely upon the heels of the victory of the Communist in China and the establishment of the Peoples' Republic of China (PRC) in October 1949, the war immediately assumed global implications beyond the boundaries of the Korean Peninsula. The North Korean attack invoked American re-intervention in the Chinese civil war, accelerated the signing of the peace treaty with Japan and focused Washington's attention toward Southeast Asia as the next target of Sino-Soviet expansion. The impact of the Korean War on the progressive American commitment and involvement in Vietnam had been extensively researched. Its impact on the United States' relations with the newly independent Indonesia, however, is much less known. This paper discusses the United States-Indonesia relations in the aftermath of the North Korean attack through to the end of the war in 1954. The newly independent Republic of Indonesia was a non-communist state but chose to be non-aligned in the Cold War. The paper explores the various ways in which the United States attempted to co-opt 
and coerce Indonesia into the Western camp in the Cold War, and Indonesia's responses thereto. The central theme of the paper is the interplay between the United States' policy of containment and the Indonesian policy of non-alignment.

\section{Background}

Before the Pacific War, Korea had been a Japanese colony. In 1905, after thwarting Russian attempt to dominate over the peninsula, Japan established a protectorate over Korea and in 1910 annexed the country; and therefore was an Axis state during the Pacific War. However at the end of the $2^{\text {nd }}$ World War and according to the American-Soviet agreement at the Potsdam Conference in July 1945, Korea was divided at the $38^{\text {th }}$ Parallel for the purpose of disarming Japanese army there. The Japanese army at the north of the $38^{\text {th }}$ parallel would be disarmed by Soviet troops while those to the south of that line would surrender to American troops. The $38^{\text {th }}$ parallel was meant to be a temporary military divide for the purpose of disarming the Japanese army but the numerous conferences between the Soviet and the American failed to unify Korea because neither side wanted to risk the possibility that a unified Korea would move into the opposing camp.

In 1948 Soviet troops retreated from the North but they left behind a communist regime headed by Kim Il Sung. In 1949, the United States withdrew from the South after establishing a government headed by Syngman Rhee. Both Kim Il Sung and Syngman Rhee were bent to unite their divided country. On June 24 1950, North Korean forces crossed the $38^{\text {th }}$ parallel to invade the south. That triggered the start of the Korean War. The so-called 'Korean War" was in essence a Korean civil-war. ${ }^{1}$

The Truman administration immediately assumed that the North Korean attack was Sovietdirected and saw it as perhaps the beginning of an extensive Sino-Soviet thrust. General Douglas MacArthur in Tokyo was ordered to provide supplies to the South Korean troops. To contain the war, the Truman administration ordered the U.S Seventh Fleet to sail between mainland China and Taiwan. A hurriedly convened session of the United Nations Security Council passed an American resolution branding the North Korean as aggressor, demanding a cession of hostilities and that North Korea withdraw its troops behind the $38^{\text {th }}$ parallel. Two days later, as the military situation worsened, President Truman ordered American air and naval units into action. That same day, the United Nations passed a resolution recommending that its members aid South Korea in restoring peace.

Many of the newly independent nations, such as India, Burma, and Indonesia among others, however, had preferred to be non-aligned in the Cold War. For many of these newly independent states, not choosing sides in the Cold War was a domestic political imperative. At the same time, non-alignment would allow them to be friends with and acquire assistance from both sides in the Cold War, a stance which neither the United States nor the Soviet Union appreciated of course. 


\section{North Korean Attack and Initial UN Resolutions}

Washington and Jakarta differed in their reactions to the Korean War. When the war broke out, the Indonesian Government issued a statement that the hostilities in Korea was yet another Cold War issue between the United States and Russia in which Indonesia wished to have no part. "North Korea is under Russian protection and the South Korean Republic is sponsored by the United States. Thus, the so-called civil war in Korea is first and foremost [a] matter concerning the two big powers in the 'Cold War,' namely the Russians on one side and America on the other." " A month later the Indonesian government issued a ban on all foreign warships taking part in UN operations in Korea from refuelling, loading or being repaired in Indonesian ports. In a statement on 27 July 1950, the Indonesian Ministry of Information explained that since Indonesia was then not a member of the United Nations it was therefore not obliged to follow the Security Council's order on aid to Korea and any vessels intending to call at Indonesian ports should submit a request to the Indonesian government. ${ }^{3}$

The State Department was especially annoyed at what it characterised as "indefensible wrong-headedness" on the part of the Indonesian republic. Merle Cochran, the American ambassador in Jakarta, was instructed to inform the Indonesian authorities that while the United States fully understood the necessity for a "new uncertain Indonesian government maintaining neutrality within limits for reasonable length of time," the Indonesian Government should understand "at this moment that in [the] struggle between USSR and [the] free world, Indonesian choice is not only unavoidable but has been made." Particularly at a time when the United States and the free world were straining to support the United Nations on the battlefield, Indonesian refusal to allow United Nations' ships port privileges in Indonesia would "be taken at worst as defection from UN and at best as aberration." Cochran also made it clear to the Indonesian government that continuation of these tendencies would "create situations in Congress and with US public opinion which will force US government to reconsider it assistance programs" to Indonesia. ${ }^{4}$

Raising the matter with President Sukarno, Cochran expressed his disappointment that Indonesia, which owed its birth so importantly to the UN and was now awaiting admission into that body, had not come out publicly in support of the UN cause. Cochran pointed out that the war in Korea stemmed from Communist North Korean aggression, with important support from the Russians; and that in fighting in Korea the United States was merely upholding its pledge to the United Nations and would continue to fight on behalf of the UNcreated South Korean state. Because of the American move in sending the Seventh Fleet to the Formosa Straits, it was not clear if Communist China would dare attack Formosa and risk a full war with the United States; but if this should happened, Indonesians "surely ought to realize more fully than ever that there is a concerted move on the part of the Communists stemming from Moscow to take over all of Asia including islands to the south." In that situation, the Philippines and Indonesia would be extremely vulnerable "if [the] Chinese, with Moscow's support, took Formosa, moved en masse over Indochina and Thailand and 
then threatened the two island republics, still weak from their birth struggles and from Communist internal machinations." Indonesians should realise that only "US force alone that can save Indonesia from Communism and that [Sukarno] should keep that in mind in his international relations." Cochran advised Sukarno that there was no place for a neutralist third path in the Cold War struggle. "I said I realized Indonesian leaders had some conceptions of a 'third force' comparable to those advanced in India. I thought time would prove, however, that when one must take sides one must feel it is a right one in such division as that which now faces the world." ${ }^{5}$ By the "right side", Cochran of course meant the American side, the 'morally correct' side.

\section{Chinese Entry into the Korean War}

American-Indonesian differences over Korea became more marked after the Chinese entered the fray in November 1950. Earlier, on 15 September General MacArthur made a brilliant landing at Inchon, just north of the $38^{\text {th }}$ parallel, cutting off a large number of North Korean troops that were occupying South Korea, and began a rapid northward march. Washington instructed MacArthur to move through North Korea if the General did not encounter Chinese or Russian resistance and if the General was certain of success in the field. On 7 November 1950, the United Nations endorsed Truman's order.

Ever since late September, Beijing had issued warning that China would not allow United Nations' troops come to the Korean-Chinese border and that indeed China would attack if UN troops moved into North Korea. The United States discounted the threat however; instead MacArthur responded by issuing an ultimatum for North Korea to surrender and continued his drive toward the Yalu. On 24 November MacArthur announced the 'end-thewar offensive.' On 26 November, Chinese troops moved across the Yalu in mass, trapping and destroying large numbers of United Nations troops, including 20,000 American and Koreans at the Chosin Reservoir. Within three weeks, UN troops had retreated below the $38^{\text {th }}$ parallel; and now, it was the Chinese who proclaimed their intention of reunifying Korea.'

Indonesian leaders, while concerned about the expansion of the war in Korea, saw the Chinese intervention as an understandable response to General MacArthur's drive northward to the Yalu, ignoring Beijing's repeated warnings. In the United Nations, Indonesia joined the Arab and Asian countries in petitioning the Peoples' Republic of China (PRC) to halt at the 38th Parallel. That Indonesian move gratified the United States. It took exception, however, when Indonesia joined other countries in abstaining from voting on the motion to discuss a resolution on the withdrawal of Communist Chinese troops from Korea. In a conversation on 8 December 1950, Cochran told Sukarno that "Indonesia should realize [that the] Chinese move into Korea [was] part of [an] overall Soviet plan to control Asia and that resolute defense on [the] continent of Asia [was] vital if Indonesia itself was to be spared.... 
Indonesia must be awake to and admit [the] danger of Communist movement southward and formulate its policies accordingly." In response, Sukarno explained to Cochran that the position Indonesia had taken in the United Nations was one which it conscientiously felt would best contribute to preventing a Third World War; that Indonesia and like-minded nations in the United Nations believed that the Korean problem might be easier to resolve in the context of a general Far Eastern settlement, one which dealt also with the status of Taiwan and with Chinese representation in the United Nations. ${ }^{7}$

Despite the refusal to accept the American thesis that China was the aggressor nation in Korea, Indonesia gradually compromised on its non-aligned stance and ultimately succumbed to American pressure. In the UN vote on 30 January 1951 on the American resolution branding China as an aggressor, Indonesia abstained, thus breaking rank with other non-aligned states like India and Burma which voted against the resolution. ${ }^{8}$ Desirous of American aid but opposed to the American position in the Korean War, Indonesia took the middle path of abstention and hoped thereby not to antagonise the United States unduly. Such was the Indonesian dilemma of dependence. 9 American officials were presumably aghast at this seeming Indonesian indifference but continued to work away at breaking Indonesia's resistance to full cooperation with the United States and its allies.

\section{Pacific Alliance: American Disappointments and Coercion}

As the military situation in Korea deteriorated, the State Department began urgently to consider the establishment of a military pact in Asia. In early February 1951, Cochran raised with the Natsir Cabinet the possibility of a Pacific Pact, embracing Indonesia, the United States, Australia and America's other Pacific allies. Mohammad Roem, the foreign minister, pointed out that such an arrangement would not be consistent with Indonesia's foreign policy of non-alignment. In response to further questioning from Cochran about the danger of possible Communist attack against Indonesia, Roem said that "Indonesia expected the United States to come to its defence in the event of Communist attack on its territory whether or not there was a formal security arrangement between the United States and Indonesia." 10

Cochran was aghast; indeed, he was extremely peeved and infuriated at the frustrations that met his persistent efforts to woo Indonesia into an alliance with the United States. In a cable of 3 February 1951, he advised the State Department:

Believe this propitious time to bring Indonesians face the realities of the world situation. US aid should not be taken for granted no matter how close our friendship has been or may continue with Indonesia. Indonesia will not only itself become a problem but will contribute to the strengthening of the AsiaticArab bloc, thereby creating a much bigger problem, if we continue too gentle a policy with this country. 
Cochran held that the Indonesians were "more likely to appreciate the benefits of such a pact if we make them realize at once that any further favors from the US must be requested and merited on its record of behavior as a sovereign nation sympathetic to the policies of the free world." 11

Cochran's State Department colleagues were immediately sympathetic with the ambassador's suggestion of getting tough with the Indonesians. In fact, this line of thinking had been gaining both momentum and adherents within the Department since the Korean War broke out. ${ }^{12}$ Reviewing the record of Indonesian relations with the United States in the Cold War, William Lacy, Director of the Office of Philippine and Southeast Asian Affairs, lamented that in the past fourteen months since Indonesia became an independent state, "many Indonesians appear to believe that Indonesia has less to fear from Communism than from American efforts to combat Communism." Despite their pressing needs, the Indonesians had been extremely reluctant to accept American technicians and economic aid. The Indonesian Parliament had finally approved the Export-Import Bank loan in early November by a vote of 90 to 17, with some $50 \%$ of the members abstaining, but thus far had failed to take any action on ratifying the US-Indonesian economic bilateral agreement. Lacy pointed out that the United States had been cognisant of the internal difficulties faced by the Indonesian government and had accordingly pursued a policy of "patience and perseverance" but that it had now become "necessary to apply more pressure in order to make the Indonesian realize that friendship between nations must be a two-way relationship."13

In late February, Assistant Secretary Rusk informed Ali Sastroamijoyo, the Indonesian ambassador in Washington, that in view of increasing US defence expenditures, Congress was expected to review the Economic Cooperation Assistance (ECA) programs critically. Rusk told Ali that this "bears no relation, for instance, to Indonesia's voting in [the] UN, although he might like to discuss this and other aspects [of] Indonesia's broad foreign policy [on] other occasion." Ali was unconvinced that the projected review have no bearing with Indonesia's foreign policy; he replied that he understood how the impression might arise, through the delicacy with which his government had to handle difficulties with the Indonesian parliament and "disorderly elements" in Indonesia, that ECA program had not been warmly received. Ali emphasised that his government "strongly desire continuance [of] ECA program," and despite the housing difficulties, it desired to receive American technicians -- "provided they are tactful and understanding" -- in limited numbers. Ambassador Ali left with a parting shot that he had heard a "rumour" recently that the United States government was considering cutting off all economic aid to Indonesia; that these rumours disturbed him and had cabled his government accordingly, but that he will now correct that this was not the case. ${ }^{14}$

The State Department's move to curtail the assistance program to Indonesia was vigorously opposed by ECA. Colonel Allen Griffin, ECA Director for the Far East, angrily charged during a luncheon with Lacy that Cochran was providing Senator McCarthy with "excellent ammunition" by wanting the United States to "pull out of Indonesia, thereby turning the 
place over to the Communists." Griffin argued that Cochran "had made an abysmal mess of American relations with Indonesia and now, by wanting to kick ECA out of the country and getting hard-boiled with the Indonesians in the matter of supporting the US in Korea, joining the Pacific Pact, and related matters, was making bad matters impossible." Griffin insisted that Cochran had personal reasons for objecting to the ECA programs and that such a negative approach was not the most effective means of combating Communism and bringing the Indonesians to the American side. The State Department defended Cochran's record in Indonesia and argued that the proposed curtailment of aid to Indonesia had nothing to do with the larger American strategy toward Indonesia. Rather, the Department's position was based on the fact that Indonesia's gold and dollar exchange position had improved so greatly during the past year that it no longer require grant aid to buy commodities or services from the United States. ${ }^{15}$ Eventually, the State Department and the ECA reached an agreement to continue the program but at a reduced level of $\$ 9.95$ million for 1951 and \$10.4 million for 1952.

\section{The Sukiman Cabinet}

The Natsir government resigned in late March 1951 as a result of a parliamentary impasse over a domestic issue and was replaced by a Masjumi-PNI coalition cabinet under the premiership of Sukiman Wiryosanjoyo of the Masjumi. Cochran was not sorry that the Natsir cabinet fell. He thought that while Natsir and Roem were "individually outstanding in ability and character," they had provided the Indonesian government with "ineffectual leadership." Moreover, "although they individually professed strong anti-Commie feelings, they never took advantage of [the] opportunity afforded them as leading party in [the] government to formulate forceful policy against Communism." He thought that Roem was "still rather naive in some of his concepts of an independent policy" and of the possible accomplishments by the Arab-Asiatic group. Cochran surmised that although "some friends" would be left out from the new cabinet, American relations with the Sukiman government could be as good if not in fact even better than with the Natsir cabinet. He anticipated that while some aspects of the new cabinet's policies "may not be Western," there was "no reason to expect anti-Western attitude." 16

The Sukiman government indeed proved to be much more congenial to the United States' interests than did the preceding Hatta and Natsir cabinets. Much to the gratification of Ambassador Cochran and the State Department, the new government pursued repressive antiCommunist measures domestically and followed a foreign policy which closely identified with that of the United States. This shift in the Indonesian position appears especially stark when compared with that of Burma and India, two other prominent Asian non-aligned states. In fact, during the tenure of the Sukiman government, Indonesia had essentially broken ranks with India and Burma on many important Cold War issues. The Sukiman government's decision to accept in February in 1952 American military aid under the terms of the Mutual Security Act, in effect consummating an alliance with the United States, 
belied the Sukiman government's claims to non-alignment in the Cold War. Significantly, it was the cabinet's flagrant pro-American foreign policies, particularly the decision to commit Indonesia to the Mutual Security Act aid, which led to its fall in February 1952.

The Sukiman government's initial response to the United Nations embargo on the shipment of strategic war materials to China, however, betrayed little of its later pro-American tendencies. Indonesia was enjoying the 'Korean boom' in rubber and tin and, as such, there were serious misgivings about observing the $\mathrm{UN}$ embargo resolution. In addition, there was also strong suspicion in Jakarta that the American motive in introducing the embargo motion was really to place the United States as a single-buyer vis-à-vis the producing countries and thus to be able to push the price of these raw materials down. And the PRC, for its part, had not been slow in playing the rubber issue. Soon after the Sukiman cabinet assumed office, the Chinese Embassy in Jakarta proposed a barter agreement whereby Indonesia would get Chinese rice for Indonesian rubber. It was with this background that Foreign Minister Ahmad Subardjo, in reaction to critical questioning at a press conference on 7 May 1951 burst out that Indonesia would "sell to the devil if it would serve the people's interests."17 This hasty statement was immediately revoked, however. The Indonesian Embassy in Washington explained that Subardjo's statement was made off-the-cuff and was meant entirely for domestic consumption. ${ }^{18}$

The State Department, in any case, was particularly anxious that Indonesia observe the proposed UN embargo. Should Indonesia sell rubber to China, the effectiveness of British embargo on rubber from British colonies to China would be destroyed. Moreover, Indonesia had no trade with China historically; and for Indonesia to change the pattern of distribution of its product particularly at a time when the United States was attempting to organise the free world against Chinese aggression in Korea would be highly delinquent. ${ }^{19}$ In a conversation on 11 May 1951, Assistant Secretary Dean Rusk told Ambassador Ali that should the attitude expressed by Subardjo became official policy; Indonesia could expect strong reactions from the United States. ${ }^{20}$ Secretary of State Dean Acheson was equally forthright. He told Ali that the State Department had been "seriously considering the economic aspects of Indonesian-US relations" and that in this connection, the United States considers the maintenance by Indonesia of its historic patterns of trade a "matter of highest importance." Any departure from the historic pattern of trade by Indonesia would almost certainly be regarded by the American public as evidence of desire on the part of Indonesia to move in the direction of the USSR and its satellites at the expense of its happy relations with the United States. Acheson tried to convince Ali that the Soviet bloc would be unable to meet Indonesian requirements and that any assistance the Soviet bloc might extend would be with "strings" attached. American assistance, in contrast, had been extended on "a friendly basis and without strings." ${ }^{21}$ Ali certainly knew better that American aid were without strings but had chosen to refrain from commenting on Acheson's remarks.

Being dependent on continued American economic and technical aid and, perhaps more importantly, hoping to procure American arms on reimbursable basis, ${ }^{22}$ the Sukiman government succumbed to this American pressure. Thus, whereas India and Burma voted 
against on the United Nations resolution placing an embargo of supplies of strategic raw materials to China, Indonesia abstained. And after strong American demarches in Jakarta, Washington and New York, it reluctantly complied with the UN embargo despite resentment at the loss of foreign exchange earnings because of the fall in the price of rubber. But Foreign Minister Subardjo managed to squeeze a small 'fee' for Indonesia's agreement to observe the embargo. Pointing to the difficult internal political situation and strong objection among the Indonesian press and parliamentarians to Indonesia subscribing to the embargo, Subardjo sought to obtain an additional $\$ 50$ million ECA loan to offset the estimated $\$ 150$ million in losses Indonesia would incur as a result of compliance with the embargo. Cochran was disgusted and he bluntly told Subardjo that the Indonesian Foreign Ministry itself had been directly responsible for stirring up this opposition. He adamantly refused to recommend any additional loan, pointing out that Indonesia had yet to make full use of past loans. ${ }^{23}$

In mid-September, however, despite Cochran's continued opposition, the ECA agreed to provide Indonesia the additional $\$ 50$ million loan. Presumably, the State Department calculated that the loan was a small price to pay for Indonesia's agreement to observe the embargo. By that time, moreover, the Sukiman government had taken several antiCommunist measures domestically. In July it had refused entry to sixteen Chinese diplomats although they all had been issued entry visa by the Indonesian consulate in Beijing. The Indonesian Foreign Ministry charged that this was the third time the Chinese had violated 'diplomatic courtesy' by failing to give adequate 'prior notification' of the arrival of new embassy personnel. Perhaps the real reason behind this move was to restrict the activities and contain the influence of the Chinese embassy among the Indonesian Chinese community. ${ }^{24}$ Perhaps even much more gratifying to American officials were the anti-Communist raids of August 1951. On the basis of an alleged Communist plot to overthrow the government, the Sukiman government suddenly launched a series of mass arrests. Some fifteen thousand persons were arrested, prominent Communist and 'leftist' leaders, several hundred resident Chinese, and the cabinet's other political enemies. In the end, however, the government was unable to convince parliament that there had been any real threat to the state and, eventually, it was forced to release those arrested..$^{25}$

On 8 September 1951, Indonesia signed the Japanese Peace Treaty, again breaking ranks with India and Burma, two other Asian non-aligned states. The latter two had boycotted the San Francisco Conference because the treaty was of American making and was intended as the cornerstone of American Cold War policy in Asia. Explaining its decision to sign the treaty, the Sukiman government stated that if Indonesia were to emulate India in concluding a separate bilateral peace treaty with Japan, "the atmosphere of good will would certainly be absent and Indonesia would certainly not be able to count on any support from the United States." ${ }^{26}$ After Indonesia endorsed the Japanese Treaty, the State Department agreed to provide the $\$ 50$ million loan which Subardjo requested. The Indonesian press was especially critical of such 'prostitution' and because of strong domestic dissent the Japanese treaty was not submitted to parliament for ratification until $1958 .{ }^{27}$ 
The responsiveness of the Sukiman cabinet to American interests and policy encouraged Ambassador Cochran to think that perhaps the time was right to try to get Indonesia to abandon non-align and align itself squarely in the American camp. In January 1952, Cochran succeeded in urging Subardjo to sign the Mutual Security Act (MSA) Agreement, which committed Indonesia to contribute fully to the "defensive strength of the free world" - implying clearly Indonesia's military commitment to the United States. The State Department had asked Cochran to urge the Indonesian to accept an alternative agreement "to maintain... world peace" and "eliminate causes of international tension" - but Cochran was convinced that the time war right to bind Indonesia to the United States since a 'rightist' cabinet was now in power. Moreover, Indonesia desperately needed American military aid. Cochran believed that Indonesia, having failed to procure military equipment on reimbursable basis from European countries, was now prepared to accept American terms. And Subardjo, on his part, believed that only through the Mutual Security Act Agreement could Indonesia secure the badly need military equipment.

On 5 January 1952, Cochran and Subardjo signed the MSA Agreement in secret. In negotiating the agreement, however, Subardjo did not consult his cabinet colleagues. Sukiman, the Prime Minister, was informed of the negotiations but neither the Minister of Defence nor any of the members of the Indonesian armed forces high command were informed. Evidently, Sukiman suspected that the term "free world" would cause problems with the Indonesian press and parliament; he asked this be changed to "peace-loving world" but Cochran refused to alter the wording of the agreement. Cochran later explained to the State Department that although he realized the risk in including the phrase "free world" in the agreement, he thought it worthwhile to attempt to draw Indonesia one step closer to the free world and prevent backsliding to the level of Burma. ${ }^{28}$ After initial hesitation, Subardjo signed the agreement.

The Cochran-Subardjo secret agreement became public when in early February 1952 American military personnel from the American embassy in Jakarta approached the Indonesian Ministry of Defence to put the recently concluded MSA agreement into effect, to the surprise of the Indonesians. Over the next few weeks, the Indonesian rained down severe criticism on the Sukiman cabinet, attacking Subardjo in particular, for both conducting secret diplomacy and the contents of the agreement. At the end of February, the cabinet was forced to resign, thus marking the passing away from the Indonesian political scene the last flagrantly pro-American government until the rise of the Suharto regime following the ouster of President Sukarno in 1966. The Sukiman cabinet was subsequently replaced by the (first) cabinet of Ali Sastroamijoyo. ${ }^{29}$

\section{Prime Minister Ali and the Pulaski Rubber Cargo}

Toward the end of the Korean War the issue of the UN trade embargo to China raised its head again in the U.S.-Indonesian relation, this time involving the Eisenhower administration and Indonesia's first cabinet of Ali Sastroamidjojo. The Ali government attached greater 
importance to foreign policy than did the previous Indonesian cabinets. Ali was especially concerned that Indonesia had veered away from non-alignment and had leaned toward the Western bloc. ${ }^{30}$ To 'correct' the situation, the Ali government stepped up relations with the Sino-Soviet bloc to counterbalance existing ties with the West. Soon after the cabinet assumed office, the Indonesian consulate in Beijing was raised to an embassy and in October 1953 Indonesia sent its first ambassador to China.

In December 1953, soon after the establishment of an Indonesian embassy in Beijing, the Ali government concluded a trade agreement with China. The total value of the trade provided for under the treaty was only \$2 million. In August 1954 the agreement was renewed for 1955 , and the value of goods to be traded was raised to $\$ 16.8$ million. ${ }^{31}$ The goods which Indonesia was to sell to China exclude strategic commodities covered under the UN embargo resolution of 1951. However, it was apparent that the Ali cabinet was seriously flirting with the idea of flouting the embargo resolution in selling rubber to China. The embargo had been politically unpopular with the Indonesians because soon after the institution of the embargo prices of major Indonesian exports dropped drastically. With the end of the hostilities in Korea, the price of rubber dropped further. Opposition to continued adherence of the embargo became increasingly vocal in 1954 with many quarters urging the government to take the lead in its recession. Indonesians generally blamed American intransigence on the rubber question as the primary cause of the serious difficulties facing the Indonesian rubber industry. Early in July 1954, amidst clamour in the Indonesian press for the government to seek additional outlets for rubber, the American embassy in Jakarta informed the State Department that some 6,000 tons of low quality rubber were being loaded aboard the Polish vessel Pulaski for shipment to the People's Republic of China. ${ }^{32}$

On 5 July 1954, on instruction from the State Department, Ambassador Cumming told Prime Minister Ali that sale of rubber to Communist China would violate the UN embargo and that the United States would be bound under the Battle Act to terminate all aids to Indonesia. Prime Minister Ali, as Cumming reported it to the State Department, while never admitting directly that Indonesia planned to ship rubber to China, explained that he was facing a dilemma: on one hand, 10 million Indonesians small-holder rubber farmers were dependent upon exports of rubber while on the other hand he was faced with adverse American reaction and possible invocation of the Battle Act plus being charged with breaching UN embargo. With respect to the latter, Ali reminded Cumming that Indonesia had abstained in the vote on the resolution. As regard to the invocation of the Battle Act, Ali said he "found it difficult to believe that in weighing relative strategic importance to the US of a few shipments of low grade rubber to China against deterioration of Indonesian-US relations, [the United States] would not sympathize with Indonesia's economic and financial situation and therefore [would] exercise discretion which he thought was permitted by [the] Battle Act." Ali further said that while American technical assistance were much appreciated and had been helpful to Indonesia, "its volume was not sufficient for it to be missed if withdrawn." Cumming reported that Ali referred repeatedly to his desire to improve US-Indonesian relations which had "deteriorated or at least lost their warmth" during the past three and a half years but 
[he have to] balance this to his duty to look after the economic interests of the 10 million Indonesian small-holders [rubber farmers]." At the end of interview, Ali told Cumming that he would "look carefully into the matter" and would let the ambassador know of the result..$^{33}$ Cumming was convinced that Ali was in fact considering a rubber transaction with China but that Ali was dragging out implementation as long as possible to test US reaction, perhaps also to improve Indonesia's bargaining position with the Chinese during the current trade negotiations with the PRC, perhaps to induce offer of financial and economic assistance by the United States; and suggested that Ali was at the same time trying not to go so far so quickly that he cannot reverse his course of action if necessary. Cumming suspected that Ali was fully prepared to face up to the consequences of the rubber shipment to China if this should be his final decision and that indeed for some time past his intentions to take such a decision had been firming. The Ambassador further believed that Ali was banking very strongly on the possibility that the United States would not take any retaliatory action under the Battle Act because of adverse effects on public opinion in Indonesia and Southeast Asia. ${ }^{34}$

Ali's response to Cumming's representation, particularly his statement that he found it difficult to believe that the United States would not exercise discretion permitted by the Battle Act, troubled American officials. If that statement was not directly refuted, the Indonesians might assume that silence was agreement and would proceed with the shipment untroubled by possible U.S reaction. If the United States were to grant Indonesia exception after first having brought great pressure on Indonesia to avoid shipment, the Indonesians would regard the United States as having been bluffing with consequent great damage to US prestige and adverse effect on future US representations on other subjects. Complicating the matter, there had been no precedence of the application of the Battle Act since this would be the first violation of the UN embargo and the United States had not terminated aid to any country because of violation of the Battle Act. ${ }^{35}$

Cumming agreed that the United States could not afford to bluff but believed that invocation of the Battle Act, should rubber in fact be shipped, would "on balance obstruct the attainment of our objectives in Indonesia." As Cumming understood it, these objectives "are to stem any drift of Indonesian policy away from one of 'independence' toward the Soviet bloc, to slow down and ultimately to turn back slow Communist influence within the government, and in the long run to deflect Indonesian policy towards a voluntary understanding and support of the US position in world affairs." Termination of American aid program would not only be used by the anti-American elements in Indonesia but "would for at least a measure of time distress our friends and weaken their quiet but nonetheless influential efforts to reduce Communist effectiveness even if they cannot orientate Indonesian policy immediately in our direction." Moreover, invocation of the Battle Act would be regarded by many Indonesians of all political shades as proof that American aid programs were primarily bribes to bring Indonesia into the American camp in the Cold War. Cumming further believed that would strengthen the position of the Ali government. Pro-government press and politicians would praise Ali for the courageous implementation of 'independent foreign policy' while the 
strongly nationalist emotions aroused by termination of US aid would make it difficult to for moderate elements both in the government and in the opposition to criticise the Ali government's decision to ship rubber to China. ${ }^{36}$

While the State Department was in a dilemma over the possible shipment of Indonesian rubber to China, President Eisenhower appeared to have been rather cool about the matter. At a National Security Council meeting in November 1953, when the possible sale of Indonesian rubber to China was first discussed, the President indicated that he could not understand why it was "a matter of such moment" to the United States if the Indonesians did undertake to sell all their rubber to Communist China. He said that he has gotten "very weary" of all these rigid controls on trade of free nations with the Soviet bloc. "Why should we not tell the Indonesians to sell their rubber and tin to China instead of having to assume blame ourselves for the inability of the Indonesians to market the products on which their economy depended?" he asked. He was utterly unimpressed with the argument that rubber had been included in the embargo list because the military authorities considered rubber to be a strategic commodity. So far as he could see, Russia had all the rubber it needed, or in any case could manufacture it synthetically. Meanwhile, the United States cannot stand forever in the way of other nations making a living. Eisenhower thought that "obviously the chief obstacle to a more intelligent approach" to the problem was the "vehemence of popular and congressional opinion" on trade between the free world and the Soviet bloc. He suggested that "what we needed most was a program to educate our own citizens on the fact of economic life." ${ }^{\prime 37}$ When the reported shipment of Indonesian rubber was mentioned again at the NSC meeting on 15 July 1954, Eisenhower thought it would be "a first-rate idea" to have Indonesia sell its low quality rubber to Communist China and that it would be best for the United States to turn a "blind side" to the transaction..$^{38}$

In the event, the matter did not come to a head because the Ali cabinet decided against shipment to China directly. On July 19, Ali informed Ambassador Cumming that the Pulaski rubber cargo was destined to London and that he had neither knowledge of nor responsibility for destination of rubber beyond London." ${ }^{39}$ Cumming surmised that the Ali government did not want to press the matter and risk punishment by the United States for violation of the UN embargo. He suggested that this change might have been accentuated by the fact that the same rubber could be shipped to the Soviet Union and Soviet satellites and even to China itself via Soviet and satellite ports. Moreover, the Indonesians were also well aware of the current moves in Washington toward relaxation of control on certain trade with China. ${ }^{40}$

Alas, however, the diversion of the shipment to London did not present a satisfactory political solution to the United States. The Battle Act Administrator informed the State Department that Indonesian shipment of rubber to an Eastern European Soviet bloc country would not trouble the United States as much regardless of the fact that Communist China was the buyer than would shipments marked for London but which in fact was delivered to Communist China because "that would involve subterfuge which would be exposed by 
reports of all kinds." The State Department suspected a distinct possibility that Communist China was buying the rubber and acting as the purchasing agency for Eastern Europe using rubber as payment to Eastern Europe on trade and financial agreement. ${ }^{41}$

The Pulaski finally departed Indonesia on 17 August 1954 with London as its reported destination. Meanwhile, it had been determined at the top level in the Eisenhower administration that in the Pulaski case, the Battle Act would not be invoked "regardless of destination." According to a policy briefing paper of 12 September 1954, compiled by the Executive Secretariat of the State Department, "The President has indicated that 'he does not want this shipment by Indonesia to create difficulties for the United States in that country,' and action under the Battle Act adverse to Indonesia will not be taken." ${ }^{42}$ A State Department circular telegram of 30 September suggested that if Indonesia made further rubber shipment to China, the United States should take the position that Indonesia's action constituted de facto withdrawal of Indonesia's listing of rubber under the UN embargo and would urge Indonesia to inform the United Nations of its intent to withdraw rubber but to continue embargo coverage in all other respects. Other countries, such as Ceylon and Malaya, could then be informed that the United States would accept something less than a complete embargo or rubber to mainland China under the Battle Act ${ }^{43}$ It was not until mid1956, however, that Indonesia actually withdrew its listing of rubber in the UN embargo.

\section{Conclusion}

It was invariable that the United States and Indonesia clashed over the Korean War, the first 'hot' war in the Cold War in Asia. In the tense international atmosphere during the early half of the 1950s, the Indonesians were understandably anxious to avoid being dragged into a possible war between the American-led Western Bloc against the Soviet-led Communist bloc. Moreover, taking side in the Cold War was a strongly divisive issue among Indonesian political parties. To American officials, however, the Cold War was an uncompromisable situation in which neutralism and non-alignment was naive, self-deceptive and even dangerous policy stance. As the Cold War in Asia deepened, American officials became convinced that Communist expansion had to be effectively contained by means of military alliances among the countries of the free world and that Indonesia must take the American side in the Cold War. The American effort to co-opt and coerce Indonesia into a Pacific alliance was a major cause of tension in post-war US-Indonesian relations.

Despite profession to the policy of neutralism and non-alignment in the Cold War, in the tug of war with the United States, Indonesia had on several occasions compromised on its stance of non-alignment in foreign policy. During the first decade of gaining its independence, Indonesia looked importantly to the West, especially the United States, for economic and technical aids. Desirous of Western and American aid, but opposed to the American position in the Korean War, Indonesia compromised on its non-aligned stance. Thus in the UN vote on the American-sponsored resolution branding the PRC as the aggressor in Korea and 
promulgating a trade embargo against China, Indonesia abstained. In contrast, India and Burma, two other Asian non-aligned states, voted against the resolution. The contradiction is instructive of course. But such was Indonesia's dilemma of dependence. It was this dilemma of dependence that served to constrain Indonesian pursuit of non-alignment during the Cold War of the 1950s.

\section{End Notes}

1 Still the best account on the origins of the war is Bruce Cumings, Origins of the Korean War, Volume 1: Liberation and the Emergence of Separate Regimes, 1945-1947 (Princeton University Press, 1981); Origins of the Korean War, Volume 2: The Roaring of the Cataract, 1974-1950 (Princeton University Press, 1992). See also the essays in Child of Conflict: The Korean-American Relationship, 1943-1953, Bruce Cumings, (Ed.) (Seattle, 1983); Peter Lowe, The Origins of the Korean War (New York: Norton, 1986). Willian Stueck, The Korean War: An International History (Princeton University Press, 1997). Stephen Casey (Ed.), The Korean War at Sixty: New Approaches to the Study of the Korean War (London: Routledge, 2012)

2 Embassy of the Republic of Indonesia, Washington DC. Report on Indonesia, Vol. 1 no. 48 (June 30, 1950), $1-2$.

Telegram, Cochran to the Department of State, 28 July 1950, Foreign Relations of the United States 1950, Vol. VI: Asia and the Pacific (Washington DC: US Government Printing Office, 1977), 1040. Hereafter this series will be referred to as FRUS.

4 Telegram, Department of State to Cochran, 26 July 1950, Ibid, 1039-1040; Telegram, Cochran to the Department of State, 28 July 1950, Ibid, 1040.

5 Telegram, Cochran to the Department of State, 26 August 1950, Ibid, 1055-1057.

6 Telegram, Cochran to the Department of State, 8 December 1950, Ibid, 1096-1098.

7 Ibid.

8 For official view on the Indonesian position on the Chinese intervention in the Korean conflict, see Report on Indonesia, Vol. II, nos. 14-19. For discussion of Indonesian position in the United Nations, see among others, Lawrence S. Finkelstein, "Indonesia's Record in the United Nations," International Conciliation, 474 (November 1951), 526-533; Evelyn Colbert, Southeast Asia in International Politics, (Ithaca: Cornell University Press, 1977) 152-160.

9 An excellent general discussion on this dilemma of dependence is Franklin B. Weinstein, Indonesian Foreign Policy and the Dilemma of Dependence: From Sukarno to Soeharto (Ithaca: Cornell University Press, 1976).

10 Telegram, Cochran to the Department of State, 3 February 1951, Foreign Relations of the United States 1951, Volume VI: Asia and the Pacific (Washington: US Government Printing Office, 1977), 145-147. Italics are mine. ${ }_{11}$ Ibid, 147

12 Memorandum, Lacy to Assistant Secretary Rusk, 5 September 1951, Ibid, 140-141.

13 Memorandum, Lacy to the Assistant Secretary for Economic Affairs, 15 February 1951, Ibid., 597-598; also see Telegram, Department of State to Cochran, 15 February 1951, Ibid, 596-597.

14 Telegram, Acting Secretary Webb to Cochran, 24 February 1951, Ibid, 606-607.

15 On the controversy between the ECA and the State Department, see Memorandum of Conversation, 15 February 1951, Ibid, 598-602; Telegram, Cochran to Department of State, 17 February 1951, Ibid, 603-605; Memorandum, Rusk to Griffin, 20 February 1951, Ibid, 605-606; Memorandum, Lacy to Rusk, 19 March 1951, Ibid, 619-623; Memorandum of Conversation, 20 March 1951, Ibid, 623-625.

16 Telegram, Cochran to the Department of State, 27 April 1951, Ibid, 642-643.

17 George McTurnan Kahin, "Indonesian Politics and Nationalism", in Asian Nationalism and the West, William Holland, ed., (New York: Macmillan, 1953), 177. Also see Soo Chun Lu, “'Trade with the Devil'; Rubber, Cold War Embargo, and US-Indonesian Relations, 1951-56”, Diplomacy and Statecraft, 19, 1 (2008), 42-68.

18 Telegram, Department of State to Cochran, 9 May 1951, FRUS 1951, VI, 647

19 Memorandum, Rusk to Secretary Acheson, 14 May 1951, Ibid, 650-652.

20 Telegram, Department of State to Cochran, 11 May 1951, Ibid, 647-649. 
21 Telegram, Department of State to Cochran, 14 May 1951, Ibid, 653.

22 See especially telegram, Cochran to the Department of State, 15 May 1951, Ibid, 655

23 Telegram, Cochran to the Department of State, 21 June, 1951, Ibid, 681-682.

${ }^{24}$ David Mozingo, Chinese Policy toward Indonesia, 1949-1967 (Ithaca: Cornell University Press, 1976), 98100

${ }^{25}$ Herbert Feith, The Decline of Constitutional Democracy in Indonesia (Ithaca: Cornell University Press, 1962), 187-192.

26 Statement by Subardjo as quoted in Indonesian Review, Vol. 1 no. 5, October- December 1951, 375.

27 Feith, Decline of Constitutional Democracy, 193-196.

28 Telegram, Cochran to the State Department, 7 January 1952, FRUS 1952-54, XII, 246-48; Telegram, Cochran to State Department, 18 February 1952, Ibid, 266-67.

${ }^{29}$ On the MSA Agreement episode, see Richard Mason, "Containment and the Challenge of Non-alignment: the Cold War and US Policy toward Indonesia, 1950-1952," in Christopher E. Goscha, Christian F. Ostermann (eds.), Connecting Histories. Decolonization and the Cold War in Southeast Asia, 1945-1962. (Washington DC and Stanford, CA: Woodrow Wilson Center Press and Stanford University Press, 2009), 57-62; Kahin, "Indonesian Politics and Nationalism", 193-94; Feith, Decline of Constitutional Democracy, 198-201.

${ }^{30}$ Feith, Decline of Constitutional Democracy, 254-255.

31 Ibid, 389.

32 Telegram, Cumming to the Department of State, 2 July 1954, FRUS 1952-1954, Vol. XII: East Asia and the Pacific (Washington DC: Government Printing Office, 1987), 435.

33 Telegram, Cumming to the Department of State, 5 July 1954, Ibid, 437-438.

34 Ibid, 439.

35 Telegram, Department of State to Cumming, 9 July1953, Ibid, 439-440.

36 Telegram, Cumming to the Department of State, 12 July 1954, Ibid, 443-445.

37 Memorandum of Discussion, NSC Meeting, 19 November 1953, Ibid, 388-394.

38 Memorandum of Discussion, NSC Meeting, 12 July 1954, Ibid, 442

39 Telegram, Cumming to the Department of State, 19 July 1954, Ibid, 450-451.

40 Telegram, Cumming to Department of State, Ibid, 447-448.

41 Telegram, Department of State to Cumming, Ibid, 451.

42 Policy Briefing for the Far East, 12 September 1954, Ibid, 469.

43 Telegram, Department of State to Cumming, September 30, 1954, Ibid, 470. See also telegram from John Steeves, Charge d'Affairs in Indonesia, to the Department of State, 2 October 1954, Ibid, 469-471. 